in developmental vascular patterning in humans. NFATc4 expression decreased significantly and NFATc2 expression remained unchanged, requiring further research. These results suggest that NFAT is involved in fetal vascular development.

\section{DOPPLER ECHOCARDIOGRAPHIC EVALUATION OF PULMONARY ARTERY PRESSURE IN LOW BIRTH NEWBORN WITH ABDOMINAL COMPARTMENT SYNDROME AFTER ABDOMINAL SURGICAL}

doi:10.1136/archdischild-2012-302724.1701

D Dmytriiev, K Dmytriieva. Anesthesiology and Intensive Care, Vinnitsa National Medical University, Vinnitsa, Ukraine

In this prospective study 16 newborn (ranging 1 day - 28 day) with severe compartment abdominal syndrome were evaluated by Doppler echocardiography for the presence of pulmonary hypertension $(\mathrm{PH})$. The goal of this study was to determine the frequency of $\mathrm{PH}$ in newborn with severe compartment abdominal syndrome because the diagnosis of $\mathrm{PH}$ influenced the treatment of pneumonia in these newborns.

The patients who had more than $25.4 \pm 1.2 \mathrm{mmHg}$ (mean $\pm \mathrm{SD}$ ) of systolic pulmonary arterial pressure were considered to have $\mathrm{PH}$. In our study $\mathrm{PH}$ was found in 13 (81.25\%) of 16 newborn. We did not find any significant difference for the parameters including the age, weight, height, clinical symptoms, signs (tachycardia and tachypnea), and laboratory findings such as hemoglobin, $\mathrm{PCO}_{2}$, $\mathrm{HCO}_{3}$ and $\mathrm{PO}_{2}$ between the patients with and without $\mathrm{PH}(\mathrm{p}>0.01)$. However, there was a significant difference in cyanosis, cardiac failure, blood $\mathrm{pH}$ level, intra-abdominal pressure and $\mathrm{O}_{2}$ saturation measured by pulse oximetry between the patients with and without $\mathrm{PH}(\mathrm{p}<0.01)$.

\section{INCREASE PLASMA ENDOTHELIN-1 LEVELS ARE ASSOCIATED WITH LUNG HYPERTENSION IN LOW BIRTH NEWBORNS WITH OMPHALOCELE}

doi:10.1136/archdischild-2012-302724.1702

D Dmytriiev, 0 Katilov, 0 Mazulov, K Dmytriieva. Anesthesiology and Intensive Care, Vinnitsa National Medical University, Vinnitsa, Ukraine

Objective Increased pulmonary vascular resistance in low birth newborn with omphalocele is suggested, and endothelin-1 plays an important role in pulmonary vascular reactivity in newborns.

Methods We determined plasma (second sample) levels of endothelin-1 in 12 low birth newborns with omphalocele and 14 without omphalocele (gestational ages: $26.2 \pm 1.4$ and $25.4 \pm 1.6$ weeks, respectively). Blood and a second blood sample taken 18 to $40 \mathrm{~h}$ after birth were used for endothelin-1 determination by enzyme immunoassay.

Result Plasma levers ET-1 concentrations were higher than second sample ET-1 levels in both groups $(p<0.001)$. There was a significant positive correlation between second sample ET-1 and SNAPPE II $(\mathrm{r}=0.32, \mathrm{p}=0.01)$. There were no correlations between plasma ET-1 levels first sample and second sample ET-1 concentrations and 5 -min Apgar score $<6$. Duration of mechanical ventilation had a significant positive correlation with second sample ET-1 $(r=0.46$, $\mathrm{p}=0.02$ ). Plasma lever ET-1 levels did not differ between control and omphalocele (13.0 and $14.6 \mathrm{pg} / \mathrm{mL}$, respectively, $\mathrm{p}=0.80$ ). Second sample ET-1 levels had significantly higher ET-1 levels than controls (1.32 and $6.04 \mathrm{pg} / \mathrm{mL}$, respectively, $\mathrm{p}=0.001)$.

Conclusion Our low birth newborn with and without omphalocele had similar plasma ET-1 levels, whereas ET-1 levels were higher in omphalocele than in control newborns 18 to $40 \mathrm{~h}$ after birth. The increased vascular resistance in omphalocele may be related to high ET-1 levels.

\section{THE USE OF INHALED NITRIC OXIDE IN A TERTIARY PAEDIATRIC INTENSIVE CARE UNIT (PICU)}

doi:10.1136/archdischild-2012-302724.1703

${ }^{1} \mathrm{C}$ Durand, ${ }^{2} \mathrm{~S}$ Mahoney, ${ }^{2} \mathrm{~S}$ Kerr, ${ }^{2} \mathrm{~N}$ Shetty, ${ }^{2} \mathrm{D}$ Buckley. ${ }^{1}$ AlderHey Children's NHS Foundation Trust; ${ }^{2}$ PICU, AlderHey Children's NHS Foundation Trust, Liverpool, UK

Aims Inhaled nitric oxide (iNO) is used to reduce pulmonary vascular resistance and improve ventilation-perfusion mismatch. This study investigates the use of iNO in a tertiary PICU - Looking at evidence of objective assessment of its benefit (important for weaning/cessation of treatment). iNO costs $£ 40 /$ hour for the first 96 hours \& free thereafter. Total spend in this tertiary Children's Hospital in the UK was approx $£ 240,000$ per annum in 2010-11.

Methods All patients receiving iNO were identified. Data was collected prospectively from the bedside (hours on iNO) and retrospectively from case notes/electronic patient records.

Results 107 patient episodes were analysed; 63\% were admitted for cardiac surgery and $66 \%$ received iNO for $<96$ hours. Analysis focused on 52 patients over 6 months. Indication for iNO was documented in $75 \%$ of cases; $48 \%$ of these patients had an echocardiogram prior to iNO. Of those in whom the indication was Pulmonary hypertension $65 \%$ had an echo, $35 \%$ had no echo. $52 \%$ of these were cardiac surgical patients. In those in whom the indication was low oxygen saturations $36 \%$ had an echo and $64 \%$ no echo. Oxygen saturations and objective improvement measures were not routinely recorded in patient records pre/post iNO.

Conclusions Main indications for iNO were pulmonary hypertension $(36 \%)$ or low oxygen saturations $(27 \%)$. $48 \%$ of patients didn't have an echo and oxygen saturations were not documented pre/post iNO. The use and effect of an expensive though potentially beneficial drug needs to be assessed and documented to justify its continued use.

\section{CEREBRAL OXYGEN SATURATION AND EXTRACTION IN NEONATES WITH PERSISTENT PULIMONARY HYPERTENSION DURING THE FIRST 72 HOURS OF LIFE}

doi:10.1136/archdischild-2012-302724.1704

MJ Mebius, EA Verhagen, ME van der Laan, AF Bos. Division of Neonatology, Beatrix Children's Hospital, University Medical Center Groningen, University of Groningen, Groningen, The Netherlands

Background and Aim Persistent pulmonary hypertension (PPHN) is a life-threatening condition treated with high oxygen concentrations in inspired air $\left(\mathrm{fiO}_{2}\right)$. Little is known about the course of cerebral oxygen saturation $\left(\mathrm{rSO}_{2}\right)$ and extraction (FTOE) in neonates with PPHN. Our aim is to explore the course of $\mathrm{r}_{c} \mathrm{SO}_{2}$ and FTOE in neonates with PPHN during the first 72 hours of life.

Methods In term neonates with PPHN $\mathrm{r}_{c} \mathrm{SO}_{2}$ was measured with near-infrared spectroscopy. Simultaneously, arterial oxygen saturation $\left(\mathrm{SpO}_{2}\right)$ was measured and FTOE was calculated: $\left(\mathrm{SpO}_{2}-\mathrm{r}_{\mathrm{c}} \mathrm{SO}_{2}\right) /$ $\mathrm{SpO}_{2}$. We obtained clinical factors such as $\mathrm{pH}, \mathrm{pCO}_{2}$, blood pressure, NO-therapy, sedatives and inotropics. We used Wilcoxon test and Spearman's correlation to test significance.

Results We included six neonates (median GA 40+2wk, BW $3900 \mathrm{~g})$. $\mathrm{R}_{\mathrm{c}} \mathrm{SO}_{2}$ increased from day 1 to day $2(\mathrm{p}=0.028)$ and FTOE decreased from day 1 to day 2 ( $\mathrm{p}=0.027)$.

Abstract 1704 Table 1 The course of $\mathrm{rcSO}_{2}, \mathrm{SpO}_{2}$ and FTOE (median, range)

\begin{tabular}{lccc}
\hline & Day 1 & Day 2 & Day 3 \\
\hline $\mathrm{rCSO}_{2}$ & $77.5(50-88)$ & $82(54-94)$ & $78(59-94)$ \\
$\mathrm{SpO}_{2}$ & $97(92-99)$ & $97(88-98)$ & $97(88-97)$ \\
$\mathrm{FTOE}$ & $0.19(0.10-0.43)$ & $0.12(0.0-0.35)$ & $0.16(0.03-0.27)$ \\
\hline
\end{tabular}

